\title{
Bypassing publicity for getting things done: between informal and formal planning practices in Finland
}

Accepted 10.9.2017 for Planning Practice \& Research (on-line-first 29 Sept., 2017)

\section{Pia Bäcklund*}

Postdoctoral Researcher, Academy of Finland Centre of Excellence RELATE

Faculty of Management, University of Tampere, Finland

Mail: Faculty of Management, 33014 University of Tampere, Finland

Tel: +358401904027

Email: pia.backlund@uta.fi

\section{Liisa Häikiö}

Professor, Faculty of Social Sciences, University of Tampere, Finland

liisa.haikio@uta.fi

\section{Helena Leino}

Senior Lecturer, Faculty of Management, University of Tampere, Finland helena.leino@uta.fi

\section{Vesa Kanninen}

Researcher, Department of Built Environment, Aalto University, Finland vesa.kanninen@aalto.fi

*corresponding author 


\section{Bypassing publicity for getting things done: between informal and formal planning practices in Finland}

\section{Introduction: tracing the idea of publicity}

This article contributes to the discussion concerning the ways in which new network governance modes and classical-modernist government practices juxtapose in planning practice. We relate this development to recent reform trends in public administration, such as multilevel and multi-actor network governance, dismantling of bureaucratic practices, and fortification of neo-liberalist thought, that have been affecting Western democracies at large (e.g. Sam \& Scherer 2006; Sager, 2009; Miller \& Rose, 2008; Hajer, 2009; Lester \& Reckhow, 2012). In this article, we focus especially on complex situations where politico-administrative processes that steer planning practice seem to actively promote both classical-modernist and network governance planning logics simultaneously - either by design or unintentionally. We see that this development may have dramatic consequences for what is seen as appropriate publicity in planning (cf. Friedmann, 1987; Dean, 2001; McClymont, 2014). Through two different planning cases, one at the system level and another at the local process level, we 1) analyse what happens to the publicity and public interaction of planning, when network governance modes and classical-modernist government practices coincide in planning practice. Based on this, we 2) discuss what kind of publicity tensions are constructed within democratic control.

As Bohman $(1999,179)$ argues, the transformations in the role and function of democratic institutions mean also new forms of publicity. Our notion of publicity follows that of Dean's (2001: 648) in which publicity is understood "to designate the norms and practices associated with the 'public"” and its "norms and practices, as well as the collectivity to which they refer, are not fixed but embedded in specific contexts". A 'strong' philosophical notion of publicity emanates from the Kantian moral 'publicity test' in which one asks, for the justness of any political act, whether one would do it if it were 'public' (cf. Luban, 1996:156). Following the Kantian ideal, Rawls (1971:454) sets high standards for publicity: for him, everyone needs to accept the same principles of publicity, and everyone needs to know that others also accept the same principles. In addition, the societal institutions need to cater for these principles and be known to do so. Christiano (2004:270) contrasts this with what he calls a "weak" publicity requirement, according to which citizens should in principle and with reasonable effort be able to see the workings of government practices. For democratic justness to be satisfied, "it is not enough that justice is done; it must be seen to be done" (ibid. 272). 
Following the above and relating them to planning theoretical insights (cf. Friedmann, 1987; Bassoli, 2010; Innes \& Booher, 2010; Aarsaether et al., 2011), we recognise a planning-focused 'practical ideal of publicity' for actions for public administration. This ideal highlights practices of transparency and openness of administration, clarity of processes and actors, as well as their roles, powers and accountabilities, proactive interaction with the widest range of participants and possibility for the citizens to affect and politicize the processes at multiple points, including agendasetting.

This practical ideal of publicity is contested by strategic planning practices that 'invite' actors to the mutual 'tables,' as the outcomes of these processes are often presented as necessities, thereby depoliticizing both form and content of the process (e.g Lester \& Reckhow, 2012). As Allmendinger and Haughton (2012:92) argue, conflict has thus not been cast away, but just been more intricately "choreographed", and sometimes displaced or marginalized. The democratic ideal conveyed is that of deliberate, situational selectivity that, from its own viewpoint, works equally for the good of the ambiguous 'us' as does representative democracy for the good of the well-defined ‘citizens' (cf. Ranciere, 1995; Zizek, 2000).

The Finnish planning system, based on a strongly regulated hierarchy of binding land use plans and a planning monopoly at municipal level yet facing the pressures of more 'strategic' approaches, highlights well the friction between a strong classical-modernist government approach and new network governance modes (cf. Hall et al., 2009; Haveri et al., 2009; Airaksinen et al., 2013). The new practices are appearing largely as a result of international neo-liberal planning ideas, yet, as Healey (e.g. 2007) has insisted, unreflected adoption of 'traveling' planning practices into new contexts may result in unintended consequences (cf. Stead, 2012). Local contexts present unique responses to global innovations mixing legislative steering, national and regional policy guidance (e.g. Friedman, 2005; Stead \& Nadin, 2009; Skelcher et al. 2011; Stead, 2012). Looking deeply to context specific cases helps us to understand better how universal planning theories and practices can be - and what are the limits of using them in different local contexts (Flyvbjerg, 2001).

The article proceeds as follows. After first discussing more closely the tensions between classicalmodernist government and governance networks in a planning context, in relation to aspects of publicity, we describe briefly the Finnish statutory planning system with which the governance networks mesh, and the processes that have contributed to this juxtaposing. In the following chapter we introduce our methodological approach and cases, and after that we analyse the empirical cases 
with attention to publicity implications. Finally, we present our findings in the discussion section, and conclude with what we can learn from the Finnish context.

\section{Government meets network governance: conflicting concepts, rules and practices?}

In recent years the relations between governance networks and governing bodies based on practices of classical-modernist government and representative democracy have been under scrutiny by many scholars and from different scientific orientations. On one hand, some studies see network governance as a threat to local democracy and politics. They argue profound tensions between procedural accountability and performance accountability (Hirst, 2000; Hendriks, 2009; Bevir, 2011; Klijn and Koppenjan, 2012), and between the democratic and technocratic forces (Griggs \& Howard, 2007; Copus et al., 2013; Herrschel, 2013; Purcell, 2013). This has been seen to promote situations in which the practices and power relations of politico-administrative processes are obscured (e.g. Beveridge, 2012; Lester \& Reckhow, 2012; Rosol, 2013). On the other hand, some of these studies have demonstrated how network governance may multiply local democracy into coexisting local democracies applying and reflecting different democratic ideas, practices and participants (Häikiö, 2007, 2010; MacLeod, 2011; MacLeod \& Jones, 2011; Sweeting \& Copus, 2012).

As Healey $(2004$; 2007) has pointed out, the overall shift away from purely classical-modernist government has been mirrored by the move from statutory planning towards strategic planning based on new governance modes (cf. Albrechts et al., 2003; Allmendinger \& Haughton, 2010; Balducci, 2011). The emerging strategic planning practices have attempted to capture the imaginative powers of urban regions and transform these into development foci that mix regulative and visionary approaches (cf. Healey, 2004). Whereas the positive theoretical discussion has emphasized their engaging and learning characteristics, critical undertones have stressed the accompanying displacement of politicisation from planning practices - highlighting central issues concerning publicity, such as accountability, transparency and legitimacy (Allmendinger \& Haughton, 2012; Mäntysalo et al., 2014a). Indeed, Allmendinger and Haughton (2010: 813) see that new practices are "short circuiting some of the formal democratic processes of statutory planning".

Highlighting the government-governance ambiguities in planning, Legacy et al. (2014) argue that while inclusive and 'public' planning cases do exist, planning has never been free of the politics of inclusion and exclusion (cf. Gunder \& Hillier, 2007; Bond, 2011; Mäntysalo et al. 2014a). In their view, planners' key position in framing the issues and processes has led to narrowing the sphere of 
actors in both classical-modernist and neoliberal approaches. In this respect, informal and neoliberal contexts might even share power and influence among a wider group of participants than 'public' planning that adheres to an assumed openness and bureaucratic-led 'decide-announce-defend' practices (Legacy et al., 2014). However, Wilkinson (2011) shows, albeit with a rather different view than ours on the virtues of such practice, that informality often helps 'getting things done' just because the perceived drawbacks of publicity can be bypassed. Similarly, Metzger (2011) emphasizes the tendencies of the selected actors in these processes to direct outcomes towards legitimizing those issues that provide benefits for themselves and advance predominantly neoliberal causes - instead of valuing them against democratic ideals (cf. Waterhout et al., 2013; CremerSchulte, 2014; McClymont, 2014).

From our viewpoint, three elements in the working logics of classical government structure the notion of publicity (Hajer, 2009): first, in the classical-modernist order, political leadership gets its mandate through elections and universal suffrage. Second, political leadership is facilitated by sector-based administrative units that are overseen by politicians (Hajer, 2009: 25), and this takes place in the public sphere. Third, the voice and role given to public interaction has gradually grown in classical modernist government: notably, Finnish legislation has developed in many sectors in the direction of encouraging citizen participation (e.g Bäcklund et al., 2014). In contrast, as Hendriks (2009: 690) describes, networks "are constellations of interdependent but autonomous actors from public, private, and societal sectors that come together for the purposes of developing and implementing public policy." Here, legitimacy has to rely on the process, the ability to gain credibility through actions, as well as through establishing a relationship with hierarchical decisionmaking. As Hajer (2009) points out, network governance is not only born out of a frustration with classical-modernist organizational practices, but also out of increasing awareness of interdependencies and willingness to explore the trajectories of mutual gain. Actors organize around particular problem, and the political drive to act is issue based. Networks are expected to be efficient and innovative in the pursuit of complex, multilevel public goals (Aarsæther et al., 2011; Klijn \& Koppenjan, 2012; Airaksinen et al., 2013).

In practice network governance, however, redefines the rules of publicity and democratic practices (e.g. Leino \& Laine, 2012). Representative institutions establish legitimate order by subjecting bureaucracies to legislature's control and legislative bodies to electorate's control (Bevir 2006, 426). Public accountability in this structure is a principle that contributes to the legitimacy of a governing system by demonstrating who is accountable for what and to whom (see Bäckstrand 
2006; Abels, 2007). Bureaucratic hierarchies and representative democratic institutions specify clear roles and procedures for making decisions. Therefore, the rules that institutions of representative democracy follow always promote some degree of formality. These outlined rules are the base of accountability as they make it possible for the public to identify who is responsible for what (Bevir, 2011), and what is the logic of planning and decision making.

Therefore, our point of view on publicity is connected to the critique of communicative and deliberative planning theories (e.g. Hillier, 2000, 2003; Mouffe, 2000, 2005; Bäcklund \& Mäntysalo, 2010). This critique asks who are the communicating parties, actors and stakeholders in each planning situation, how do they come by their roles as deliberators, what can be discussed and which issues are to be taken as given in each situation (Lester \&Reckhow, 2012). Like many others, we highlight that complexity in planning includes not only issues of ontological and epistemological differences about what is a 'good life' or a 'good city' and how value-led decisions are arrived at (McClymont, 2014), but also questions such as what kind of processes should be incorporated in planning and why (e.g. Sager, 2009; Campbell, 2012; Forester, 2013; Inch, 2015).

\section{Local context: mixing statutory and informal planning in Finland}

In Finland, spatial planning in the classical-modernist government model has traditionally aimed at transparency of actions, in accordance with Nordic welfare state ideals (e.g. Bäcklund \& Mäntysalo, 2010; Mäntysalo \& Saglie, 2010; Mäntysalo et al., 2014a). The Land Use and Building Act (2000) attempts to increase the publicity of planning by obligating a formal "participation and interaction plan" in every planning process. It lists known participants, principles of participation, and an outline of interaction between the planning authority and the citizens. In addition, e.g. the Constitution, Act on the Openness of Government Activities and the Local Government Act obligate all public activity to transparency and fostering of citizens' right to participation. The expectancy of administration adhering to these principles is good, as the government has been considered reliable and just by the public (cf. Erkkilä, 2010). Hence, in the statutory planning system, processes and actors are well (pre)defined and public, so it is possible for citizens to be well-informed of on-going and future planning activities.

What is noteworthy in the Finnish system is that the municipalities enjoy a planning monopoly within their territory. The Finnish statutory land use planning system, with three tiers of binding land use plans (regional plan, master plan, detail plan), has up until recently contained the planning practices in uniform fashion throughout the nation. The regional plan is a joint municipal activity 
and the two lower tiers are municipal. The plans, once approved, are binding and must be accounted for in lower-tier planning and eventually in development control, which, subsequently, is mostly a technical process if the plan requirements are met.

However, the statutory planning system has proved unable to fully address the increasing complexity of planning issues. For example from a city-regional point of view, municipal master planning is considered prone to advancement of municipal rather than city-regional issues (e.g. Laitio \& Maijala, 2010). Therefore, the state has been actively instigating new planning innovations, both with an explicit intent and by creating conditions for new practices.

In this vein, recent legislation within the government programme to reform of municipal structures commanded the 17 largest city-regions to produce roadmaps to realising integrated land use, housing and transport planning. The legal obligations were instigated without provision of additional tools, so the city-regions needed to build up procedures with which they could provide proof of integrative cooperation. In spite of the possibility and legal rights for the city-regions' municipalities to prepare statutory joint master plans, the city-regions turned to informal strategic planning (Mäntysalo et al., 2014b).

Likewise, the roles of the two statutory municipal planning levels have been discussed in the light of new informal planning initiatives (e.g. Mäntysalo et al., 2015; Kanninen, 2016). The two-tier approach has often proved too time consuming and limiting for fast-paced urban development, so master planning is often neglected in favour of detail planning. This creates a strategic gap in the planning hierarchy. Hence, privately initiated and/or produced site- or suburb-level "master plans" that resemble statutory plans have appeared (cf. Laitio \& Maijala, 2010). Lately, municipal planning authorities themselves have adopted similar concepts. Such plans intend to guide detail planning, yet their legal position and legitimacy are ambiguous. "Strategic" city centre development plans have also been produced outside the statutory planning system in several Finnish cities.

These developments mark the appearance of a profound tension between two parallel lines of planning: formal statutory, government-based land use planning accepted by representative democracy practices, and new informal, governance networks -based strategic spatial planning instruments with ambitious goals but ambiguous connections to both statutory plans, democratic control and the ideal of publicity. Remarkably, instead of actively seeking to develop new mechanisms of statutory planning to meet the challenges of complex urban development issues, the 
state has actively supported a parallel informal system and new tools. The relation between these tools and statutory planning, with its publicity principles set in legislation, is unclear in many ways.

\section{Methodological approach, data and analysing contexts}

Our examples illustrate two different levels - system and process - of how the government and governance logics mix in the spatial planning context in Finland. As our objective is to reveal how changes in Finnish planning culture affects approaches to publicity, our interest centers on how new planning practices, which operate around and across the government- and governance-based models, obscure the principles of publicity in planning. We aim at locating the underlying, often implicit and hidden mindsets that frame planning practices and may, inadvertedly, unnoticed or just in silence, narrow the practices and principles of publicity.

Our methodological approach is related to "phronetic planning research" that investigates questions of power and values for specific instances of planning (Flyvbjerg 2004). Also in line with Foucault (1972; cf. Forester, 2012; Wagenaar, 2011), we try to make visible the 'mentality' of governing, reflected in what is acceptable and allowed in practice. In this context, understanding the reality of planning - also as it is construed for different actors - is important (cf. Forester 1984; Sager, 2009; Olson \& Hysing, 2012). Our main analytical approach is interpretive policy analysis (Wagenaar 2011), which for us means following the acts - agreements, plans, practices - that justify some issues, solutions and strategies as appropriate, while marginalising others. In doing so, they also justify some ideas of publicity over others.

In our first case (MAL, ch.5) we describe and analyse the active state support to a governance network model at the city-regional level in parallel to the government-based statutory planning at a planning system level. We begin by describing the processual change and introduce the new informal planning tools used. After this, we analyse the publicity implications of the new procedures. First, we study the ways in which publicity practices are explicated in informal documents. Second, we analyze the referential relations between the informal documents and the statutory planning documents that are bound by legal publicity principles. Our aim is to find out how different parts of the emerging planning system and its (formal and informal) instances relate to one another, and what publicity implications follow (cf. Sager, 2009:79). Previous research concerning the experiences of these new tools (e.g Ojaniemi, 2014; Mäntysalo et al., 2014b, 2015) is utilised throughout the case. Our analysis spans years 2007-2016. 
In the second case (Lempäälä, ch. 6) we analyse how network governance procedures infiltrate and mix with government-based statutory planning in a municipality-level planning process. The Lempäälä case makes visible the new forms of governance by looking at a governance network and its relation to formal planning from the point of view of the local policy makers. The case focuses on a visionary planning group operating in the municipality of Lempäälä 2010-2013. The data in the Lempäälä case consists of official minutes of the meetings of municipal executive board and municipal council 2010-2013, the interviews of the twelve members of the Lempäälä municipal executive board (done in autumn 2012), newspaper articles related to the planning case 2010-2013, and planning documents.

The data were analysed to explore the chain of events and to look for the elements of publicity of the processes. After the first phase analysis and building the structural relations and timeline we concentrated on the in-depth document analysis and interview analysis. We wanted to understand how both the texts and actors position the public and publicity. Through interpretative policy analysis lenses (cf. Hajer \& Wagenaar, 2003; Wagenaar, 2011) we explore the framing of policy statements rather than treat these as given (Yanow \& Schwartz-Shea, 2006). We look at how planning policy is conducted, and how actors deal with ambiguous and overlapping planning policy practices in situ (Hajer \& Laws, 2006: 262-263). Analysis sheds light on the mechanisms that the actors use to manage ambivalence. We are interested in finding out the strategic spots at which ambiguities relating to publicity arise.

\section{MAL: tensions between legal responsibilities and getting things done}

An example of the novel informal procedures at city-regional level depicted in chapter 3 is a specific national-level system of MAL agreements. The state and the municipalities within the four largest Finnish city-regions (Helsinki, Tampere, Turku, Oulu) have entered into informal cityregion specific agreements concerning integrated "MAL" - land use (M), housing (A) and transport (L) - objectives (first round 2011-12, second round 2013-15, latest round 2016-19). These agreements aim at producing a common understanding and programming of strategic spatial development in the city-regions, and ensuring state commitment in providing funding for infrastructures. Each agreement is unique, dealing with the city-region specific issues and operationalisations. 
Due to the state requirements of city-regional MAL cooperation, informal strategic planning had become almost a fashion in the city-regions by the end of 2000s. Especially so-called "structural schemes", providing spatial articulations of city-regional strategic development issues, became a popular tool. Schemes are cross-sectoral and inter-municipal documents that have no legal status per se (e.g. Mäntysalo et al., 2015). In light of the seeming success of the early ones as vehicles of city-regional strategic unification, the state started to promote their use as the basis for negotiations in the MAL agreement processes.

The general ambiguity between legal responsibilities and getting things done is well visible in MAL agreements. In line with what Sager $(2009,66)$ depicts as the role of neoliberal planning, induced activity and common ideas are seen primary to the procedural aspects. This means that case- and situation-specific interpretations of what is the role of democratic control and what constitutes necessary publicity prevail. In the preparation for the agreement system, the state acknowledged some shortcomings in the technical, legal and political aspects of the schemes (VN, 2009). While it was also acknowledged that citizens and stakeholders rarely have knowledge or possibilities to acquire knowledge of these processes, no remedies were considered in relation to publicity. A recent study (Mäntysalo et al., 2014b) confirms that generally, citizens are not accounted for in the stakeholder interaction concerning the preparation of structural schemes. Those involved in MAL planning practices see this mostly unproblematic (Ojaniemi, 2014; cf. Allmendinger \& Haughton, 2012). In her interviews of MAL practitioners, Ojaniemi (2014: 17) notes that

The general opinion was that citizen participation needs not be included in MAL agreement proceedings, since democracy is realised as representative through municipalities. On the other hand it was seen in the regions that activity that takes citizens into consideration is realised in the structural scheme work.

The relation between the structural scheme work and statutory planning is unclear, and even at best, the publicity and participatory activities do not compare to those of statutory planning. The inclusion of elected representatives has been sporadic and their role ambiguous (Ojaniemi, 2014). This is crucial shortcoming in terms of democratic control, given that the structural schemes play an important role in MAL agreements.

This is not to say that the structural schemes and other informal background documents are without merit: on the contrary, e.g. some of the schemes are sound and viable strategic plans with potential for the realisation of their objectives. However, concerning the publicity and the democratic control 
of planning, a fundamental issue is present: the more the city-regional informal planning agreements define the objectives and procedures, the less real possibilities there are to politicize those issues within formal planning processes, where publicity principles would allow for it both in principle and in practice. When statutory planning documents are subordinated to operationalisation vehicles in the MAL agreement process, there is even less space and motivation for participation in statutory processes. MAL agreements can thus bypass the spirit of the Land Use and Building Act that emphasises the publicity of planning. Since the operational modes of city-regional cooperation are not well established, it is difficult for the citizens to know how issues related to their lives are being planned and decided upon. The following quote shows how formal participation in statutory planning is considered irrelevant by the citizens when the framing decisions are made in informal processes:

\footnotetext{
MAL agreements are important in this process, but unfortunately the so-called general public, including the voluntary organisations, cannot participate in relation to them at all, which is regrettable. MAL work makes big principal decisions concerning land use. The starting points and principles of the work should be better explicated. (The Finnish Association for Nature Conservation, Uusimaa district, statement on Helsinki region transport system plan 27.1.2014)
}

In creating the agreement system, the state has chosen to encourage informal integrative strategymaking. The alternative, as e.g. Mäntysalo et al. (2014b, 2015) point at, would have been to develop the existing statutory instruments - that include commonly accessible publicity protocols - into functional strategic tools. Neither has the inclusion of formal documents, with clear publicity implications, been promoted in the agreements. According to our analysis, the practice has been to the contrary: for example, in the Oulu city-region, the statutory joint city-regional master plan has been side-tracked as the basis for negotiations. In others, the formal planning documents are mentioned as a basis only in the Helsinki region.

Also, the relations between the background documents, such as the structural schemes, and the actual agreements are variably difficult to decipher. For some agreements, there is little or no additional information available for coming to terms with on what the final agreement terms were based on, whereas in others, the relations are, on the surface, quite transparent. There are ambiguities also in how the agreements present different city-regional and municipal documents as "basis", "guidance" or even "documents aiding in reaching the agreement objectives" that points at a subordinate role in relation to the agreements. Given this ambiguous nature of the background documents, there is a double layer of ambiguity and opaqueness around the processes. 
A further issue is an ambiguous relationship between MAL agreements and sectorial planning. According to the MAL Network study (MAL-verkosto, 2010), the relationship between MAL and other planning activities in the city-region is mainly information exchange between individual civil servants. The simultaneous processes of government (e.g. statutory planning on different levels, housing policies, transport system planning) are generally not harmonised or in compliance with each other, so active informal processes add to the pre-existing ambiguity and dissonance:

It isn't enough that one knows the content and aims of one planning process, in the worst case one needs to know several parallel planning documents, their mutual relations and the power relations of the parties. As an example, Helsingin seutu, where one has to simultaneously understand municipal strategies [4] and planning processes [at general and detail levels], the regional plan, [Helsinki] region land use programme, transport system plan, MAL agreement and its supplementary agreement; all of them have their own decision making processes and levels of binding effects. (comment at a workshop concerning MAL agreements)

However, this is not yet the full measure of ambiguity surrounding MAL planning. Outside the agreements, so-called "MAL planning" processes exist in many urban regions, and within the municipalities as well. If anything, "MAL planning" has become a buzzword that, as rhetoric, functions similarly to "sustainable development" (Mäntysalo et al., 2014b). These MAL planning practices are generally ad hoc and equally ambiguously connected to the formal planning system as are the agreement processes (e.g Mäntysalo et al., 2014a). There is also an ad hoc institution, the MAL Network, that links MAL planning authorities in 17 city regions, acting as an information and activity hub.

The MAL case shows how novel informal procedures that hover between governance and government logics may effectively transform the notion of public planning and in doing so, endanger the publicity of planning in multiple ways. The most profound challenges concern the ambiguous roles and 'places' of actors and procedures: even though the signatories of the agreements are the state and the city-region's municipalities, legitimate public actors, the content and the objetives of the agreements are based on informal processes and plans. Their relation to formal government-based statutory planning processes and plans remains unclear. The agreements are often in a tensioned relation with municipal plans and strategies, not least because they follow a different logic of publicity. Yet another story, worth mentioning but outside the scope of this study, is that the state is anything but a singular actor - signing for the state are half dozen ministries and state institutions that not necessarily share common ideas across the MAL spectrum. Furthermore, 
the financial commitment of the state is politically conditioned and tied to the government term and the annual state budget negotiations, so it is unclear whether the MAL agreements would survive changes of national political climate.

\section{Lempäälä: mixing novel and traditional rules}

Lempäälä is one of the neighbouring communities of the city of Tampere. The wider Tampere Central Region (345 000 inhabitants) is one of the most rapidly growing areas in Finland. Currently, within the region there is an urgent need for new housing, which is given a top priority in urban planning (Leino, 2012). However, the previous planning decisions made in recent decades have been scattered single plans here and there, lacking overall strategy. As a consequence, in Lempäälä the commercial locus has moved away from the old centre to the nearby nationally well-known Ideapark shopping centre. The Lempäälä municipal council awoke to the grim state of the old community centre in 2008, couple years after the mega-sized Ideapark shopping centre was opened.

First the municipality organized public hearings and several other participatory seminars for the inhabitants in order to gather ideas to revitalize the old municipal centre (Karppi et al., 2008). Nevertheless, the outcomes of the public participatory projects did not proceed as concrete operations. Regarding to a member of the municipal executive board, the reason was in the quarrelsome municipal council that could not find a common understanding about the issue:

\footnotetext{
We have a history of very conservative progress (in land use planning). We have never had the courage to take great leaps. One reason are the landowners, without a proper vision we have not convinced the landowners to come along. And there have been visions and pictures previously as well, but they haven't changed a thing. (Interview 4, 12.10.2012)
}

The Lempäälä visionary group, formed in 2010, attemps to advance the development of the centre by promoting fluid network governance collaboration. The role of the group has been very clearly that of an issued based problem solver. The group is connected to formal structures by municipal executive council acting as a steering group. Several official documents, such as the minutes of the meeting of municipal executive board, describe public activities being at the crossroads of governance emphasising broad cooperation and government emphasising formal decision-making power.

The progress from Lempäälä visionary process into the implementation phase has continued with extensive interaction together with landowners, inhabitants, building companies, sponsors, and franchising groups. Novel modes of cooperation have been found between YIT Construction Company, 
parish and municipality. The letter of intent made between these partners is not restricting the public interaction. It does not effect on the content of the plan, which is implemented and informed according to the legal administrational practices. (Minutes of the meeting, municipal executive council, March, 2012)

The local newspaper expanded even the notion of public activities beyond decision-making bodies to local community and residents:

The future of our municipal centre is not dictated by construction companies. Instead, the construction companies will build exactly the kind of service buildings and dwellings that the citizen of Lempäälä want. [...] (Local newspaper Lempäälän-Vesilahden Sanomat (7.3.2012)

At first sight, the visionary group thus seemed to have a clear and legitimate local position: during 2011-2012, the group arranged over 50 meetings each year with stakeholders such as landowners, local enterprises, construction companies, scientific experts, municipal departments and so on. It organized, together with the municipality, five public hearings targeted to local residents. The local municipal executive board received information about proceedings semi-annually, and a special meeting was arranged for them twice.

The group was, however, created by the municipal manager alone, which afterwards caused critique among the members of municipal executive board. Also, the financial support given to the group was not clear for the members of municipal executive board:

The visionary group came as a surprise; suddenly we hear that this group exists. It appears to be a great and a new kind of project which doesn't lean too much to the old models. But I just wonder who finances the meetings of this group? (Interview 1, 23.10.2012)

One source of criticism was that the interaction among stakeholders focused very much around local entrepreneurs and business life. The visionary group was keen to make the visionary work and present their results to diverse local municipal organs. This raised doubts among the members of the municipal executive board, who questioned the sincerity of nature of interaction:

Who is governing this process? Everyone should go beyond their "safety areas", especially the visionary group. They are in clouds, in a safe harbor visioning by themselves. This group is a closed circle of men. There should be varying members, for example we from the executive council could take part to their meetings. A changing member who would make questions and challenge their vision. (Interview 8, 11.10.2012) 
The visionary group organized us a seminar, where the original idea was to gather our wildest visions from the future development of Lempäälä centre. But this was not the case, it was a seminar with very tight schedule. [...] the objective of this seminar was to support the decision making process and not to vision anything new. (Interview 3, 11.10.2012)

The Lempäälä case brings forward the notion how local public activity is framed by mixing rules of government and network governance. This creates tensions between new and old rules, between networks and formal planning authorities and government bodies. Planning practices in this case establish public activity beyond formal institutional arrangements of local government. Formally the governance network was closely tied with local government executive board. Visionary groups' legitimate position for taking public activities was based on this relation. But in practice, the executive board is one stakeholder to be informed and discussed with. According to the interviewees, it was unclear if the executive board was able to have influence on future plans.

The visions produced by the group were brought to public no sooner than after a few months. Local newspaper published images of the vision and municipality organised a public hearing. We interpret this to show how the 'government side' of planning activities, municipality as a legal actor, feels the need to adhere to the legal obligations concerning publicity. However, after the public hearing the discussion moved back to the non-public arena to discuss with the key landowners about the vision in more detail.

As Beveridge has highlighted (2012: 47) all actor groups are not always subject to the formal rules and responsibilities of the political system, and their activities undermine the democratic legitimacy of political decision-making. The outcomes for these kinds of issue-based cooperative working groups are often unclear in terms of transparency, democratic legitimacy and liability (cf. Sheppard et al., 2015). The more planning, decision making and service provision is organised through informal partnerships (including e.g. new private sector actors), the less possibilities remain for citizens to influence through the traditional practices of representational democracy.

The democratic dilemma of the process is disconnection between responsibility and power: one could ask who are the actors bargaining 'at the table' about the agenda, and from where have they received their mandate (cf. Hillier, 2000; Lester \& Reckhow, 2012)?

Charismatic people have power, and in the group you can find them. This is all right, if power is used for public good. And we have needed these well-known gentlemen in this process, but it is the certain 
kind of pushiness and own excellence of that this group has, which cuts off other viewpoints. Domineering people rule out other visions. (Interview 6, 18.10.2012)

Politician should be, and they want to be cautious in their opinions. They need to have public support for their views. Visionary group can quite carelessly suggest whatever they want to, they don't make decisions and they are not carrying the economical responsibility of these kinds of projects. (Interview $1,23.10 .2012)$

The visionary group was not responsible for the economic or other societal aspects of the vision, and the institutional rules applied the municipal executive council did not concern the work of the visionary group. After 2013, the planning process moved on to the detailed agreements made between the Lempäälä municipality and individual construction companies. The publicity of the process and the agreements at this point was tenuous and vague.

\section{Discussion: politics without publicity?}

In this paper, we have analysed the ongoing transformation of the Finnish planning culture by asking what is the new form of publicity that the Finnish planning system and planning practices currently manifest. Because the Finnish planning system has been considered very clear-cut, the appearance of new governance models affects the well-established democratic foundation and the transparency of public action perhaps more profoundly than in countries with fundamentally more networked and policy-oriented planning cultures and systems (cf. Nurse, 2014; Heurkens \& Hobma, 2014).

The MAL-case shows how even the foundations of municipal democracy can be seen to be under legitimate threat, given that the state has actively started to promote, parallel to the statutory planning system, forms of inter-municipal networking that are ambiguous in both mandate and relation to formal planning and institutions of representative democracy. This undermines the principle of municipal self-determination, embodied in the municipal planning monopoly, as new planning tools define spatial development at the city-regional level without clear reference neither to the statutory planning system nor to any principles thereof. The state therefore both supports municipal self-determination by emphasizing its constitutional importance, and erodes it by supporting new planning procedures that enable bypassing practices of formal planning within municipal democracy. 
Lempäälä case shows the same phenomenon at the local level - how networking practices bypass the established bureaucratic and democratic institutions. Actors receive a certain mandate from the system of representative democracy, e.g. by representing a municipal administration branch under political control, yet function in a network environment that does not follow the logic of representative democracy. The democratic practices are being abandoned or redefined to suit the legitimisation of governance practices. Issues are being solved without any interventions from public deliberation being allowed to affect the objectives, even if this results in seemingly 'public' activity.

We see that our cases present well the ease with which procedures and actions that undercut publicity have made their way into Finnish spatial planning. This ease may be partially explained by what Airaksinen et al. (2013) have argued: the Finnish public sector actors do not see network legitimation as all that important in relation to publicity and democratic anchorage, since networks are considered to be mostly practical (technical) instruments for planning, not places for politics and politicization of issues. In this vein, our analysis points at arena-shifting that may lead to depoliticizing city-regional strategic planning: by subordinating the public planning processes to MAL agreement processes, the space for reciprocal discourse and justification is narrowed (cf. Rawls, 1997:771) and 'choreographed' out of the sphere of publicity (cf. Allmendinger and Haughton, 2012). In the last instance, the question about the principle of publicity and the justification of action is a question of the extent to which the communicative, political and technical dimensions of planning processes are seen as separate or interlocked (cf. Kanninen et. al., 2013).

This apparent opaqueness in network cooperation - spanning structures, processes and objectives hinders the possibilities for excluded stakeholders, such as citizens' self-organizing groups, to politicize issues effectively. This results from the fact that the potential target of politicization is already planned and decided upon, and citizens may not know by whom, how and when new ideas enter the agenda, as the MAL case points out. In addition, if the planning process is organised in a way that excludes some of the elected representatives, the representatives may also be poorly aware of the content, like Lempäälä case shows. Hence, the less established the network cooperation is, the more it shrinks the sphere of 'the public', thereby demanding that potential stakeholders and citizens have active antennae for finding out the places for effective participation. 


\section{Conclusion: planning as 'skimming the cream'?}

Our cases show how novel and ambiguous relationship between the statutory planning process and strategic planning practices makes it alluring to keep publicity at bay if possible - not necessarily for the sake of knowingly bypassing publicity, but for getting things done without 'unnecessary complications' and for increasing the perceived quality of outcomes. Even Christiano's (2004) 'weak' notion of publicity is not satisfied in our cases, since is it not plausible to think that the 'public' may even in principle become knowledgeable about the planning agendas when they are in the making. It may be considered that as these new practices gain ground and become more and more embedded into the public administration, even displacing current statutory practices, that a new public administration logic is arrived at. In it, actions are rooted in issue-related performative and technical aspects of problem-solving, legitimacy is claimed by reference to established institutions, and responsibilities are blurred and diluted into the ambiguity of networks.

Side-stepping from the statutory planning system into the ambiguous domain between government and governance logics enables two important deviations: first, since these practices are not statutory or even 'formal' in legal terms, their operations are not covered by the specific legislation that obligates the arrangement of publicity. Second, the informal nature of the networks enables seeing these activities as not belonging into the 'planning' category where democratic practices would be at least morally implicated. The openness of preparing the agenda and the possibility to follow how outcomes are reached are subsequently lost. Whether or not this happens intentionally, it nevertheless enables these to operate in the 'twilight zone' of publicity ideals. The crucial and classical planning question still remains: does the possibility of positive outcomes legitimize the process, even when the process operates in a democratic void? The Finnish cases show that with developing planning practices from the point of view of planning goals only, multiple societal effects may be left unaccounted for. These include ideas of acceptable publicity and functional democracy. Of specific interest is that the state seems to actively support this development.

We argue that new modes of governing utilize - and construct - institutional ambiguity for getting things done. Tensions between networks and traditional representative democratic institutions provide leeway for asserting authority without explicit rules or legal duties. The combination of network governance and classical-modernist understanding of publicity and democracy provides prospects for 'skimming the cream' of the best options of resolving issues without public obligations that prevent reaching the issue-based goals. 


\section{References}

Aarsæther N., Nyseth, T. \& Bjørnå, H. (2011) Two Networks, One City: Democracy and Governance Networks in Urban Transformation, European Urban and Regional Studies, 18(3), pp. 306-320.

Abels, G. (2007) Citizen involvement in public policy-making: does it improve democratic legitimacy and accountability? The case of pTA, Interdisciplinary Information Sciences, 13, pp. $103-116$.

Airaksinen J., Härkönen H. \& Haveri, A. (2013) Perceptions of Legitimacy in Nordic Regional Development Networks, Public Organization Review 14, pp. 457-476.

Albrechts, L., Healey, P. \& Kunzmann, K. R. (2003) Strategic spatial planning and regional governance in Europe, Journal of the American Planning Association, 69(2), pp. 113-129.

Allmendinger, P. \& Haughton, G. (2010) Spatial planning, devolution, and new planning spaces, Environment and Planning C, Government \& Policy, 28(5), pp. 803-818.

Allmendinger, P. \& Haughton, G. (2010) Post-political spatial planning in England: a crisis of consensus? Transactions of Institute of British Geographers, 37, pp. 89-103.

Balducci, A. (2011) Strategic planning as exploration, The Town Planning Review, 82(5), pp. 529546.

Bassoli, M. (2010) Local Governance Arrangements and Democratic Outcomes (with Some Evidence from the Italian Case), Governance: An International Journal of Policy, Administration, and Institutions, 23(3), pp. 485-508.

Beveridge, R. (2012) Consultants, depoliticization and arena-shifting in the policy process: privatizing water in Berlin, Policy Sciences, 45(1), pp. 47-68.

Bevir, M. (2006) Democratic governance: systems and radical perspectives, Public Administration Review 66(3), pp. 426-436.

Bevir M (2011) Governance and governmentality after neoliberalism, Policy \& Politics 9(4), pp. 457-71.

Bohman J. 1999. Citizenship and Norms of Publicity: Wide Public Reason in Cosmopolitan Societies. Political Theory, 27(2): 176-202.

Bond, S. (2011) Negotiating a 'democratic ethos': moving beyond the agonistic-communicative divide, Planning Theory, 10(2), pp. 161-86.

Bäcklund, P. \& Mäntysalo, R. (2010) Agonism and institutional ambiguity: Ideas on democracy and the role of participation in the development of planning theory and practice - the case of Finland, Planning Theory, 9(4), pp. 333-350.

Bäcklund, P., Kallio, KP. \& Häkli, J. (2014) Residents, customers or citizens? Tracing the idea of youthful participation in the context of administrative reforms in Finnish public administration, Planning Theory \& Practice, 15(3), pp. 311-327. 
Bäckstrand, K. (2006) Multi-stakeholder partnerships for sustainable development: rethinking legitimacy, accountability and effectiveness, European Environment, 16(5): 290-306.

Campbell, H. (2012) Planning ethics and rediscovering the idea of planning, Planning Theory ,11(4), pp. 379-399.

Copus, C., Sweeting, D. \& Wingfield, M. (2013) Repoliticising and redemocratising local democracy and the public realm: why we need councillors and councils, Policy \& Politics, 43(3), pp. 389-408.

Cremer-Schulte, D. (2014) With or Without You? Strategic Spatial Planning and Territorial ReScaling in Grenoble Urban Region, Planning Practice \& Research, 29(3), pp. 287-301.

Cristiano, T. (2004) The Authority of Democracy, The Journal of Political Philosophy, 12(3), pp. 266-290.

Dean, J. (2001) Publicity's Secret, Political Theory, 29(5), pp. 624-650.

Erkkilä, T. (2010) Reinventing Nordic Openness: Transparency and State Information in Finland, Acta Politica (Helsinki: University of Helsinki).

Filgueiras, F. (2016) Transparency and accountability: principles and rules for the construction of publicity. Journal of Public Affairs, 16(2), pp. 192-202.

Flyvbjerg, B. (2001) Making social science matter. Why Social Inquiry Fails and How it Can Succeed Again (Cambridge: Cambridge University Press).

Flyvbjerg, B. (2004). Phronetic planning research: theoretical and methodological reflections. Planning Theory \& Practice, 5(3), 283-306.

Forester, J. (1984). Bounded Rationality and the Politics of Muddling Through. Public Administration Review, 44(1), 23-31.

Forester, J. (2012). Learning to Improve Practice: Lessons from Practice Stories and Practitioners' Own Discourse Analyses (or Why Only the Loons Show Up). Planning Theory \& Practice, 13(1), 11-26.

Foucault, M. (1972). The Archeology of Knowledge. London: Tavistock Publications Ltd.Forester, J. (2013) On the theory and practice of critical pragmatism: Deliberative practice and creative negotiations, Planning Theory, 12(1), pp. 5-22.

Friedmann, J. (1987) Planning in the Public Domain. From Knowledge to Action (Princeton, NJ: Princeton University Press).

Friedmann, J. (2005) Globalization and the emerging culture of planning, Progress in Planning, 64, pp. 183-234.

Griggs, S. \& Howard, D. (2007) Airport governance, politics and protest networks, in: M.

Marcussen \& J. Torfing (Eds) Democratic network governance in Europe, pp. 66-89 (Basingstoke: Palgrave).

Gunder, M. \& Hillier, J. (2007) Planning as urban therapeutic, Environment and Planning A, 39(2), pp. 467-86. 
Hajer, M. (2009) Authoritative Governance. Policy-making in the Age of Mediatization (Oxford: Oxford University Press).

Hajer, M. \& Laws, D. (2006) Ordering through Discourse, in: Michael Moran et al. (eds.) The Oxford Handbook of Public Policy, pp. 249-266.

Hajer, M \& Wagenaar, H (2003) Deliberative Policy Analysis. Understanding Governance in the Network Society (Cambridge: Cambridge University Press).

Hall, P., Kettunen, P., Löfgren, K. \& Ringholm, T. (2009) Is there a Nordic Approach to Questions of Democracy in Studies of Network Governance? Local Government Studies, 35(5), pp. 515-538.

Haveri, A., Nyholm, I., Røiseland, A. \& Vabo, I. (2009) Governing Collaboration: Practices of MetaGovernance in Finnish and Norwegian Local Governments, Local Government Studies, 35(5), pp. $539-556$.

Healey, P. (2004) The treatment of space and place in the new strategic spatial planning in Europe, International Journal of Urban and Regional Research, 28(1), pp. 45-67.

Healey, P. (2007) Urban Complexity and Spatial Strategies: Towards a Relational Planning for Our Times (London: Routledge).

Hendriks, C. (2009) The Democratic Soup: Mixed Meanings of Political Representation in Governance Networks, Governance: An International Journal of Policy, Administration, and Institutions, 22(4), pp. 689-715.

Herrschel, T. (2013) Competitiveness AND sustainability: can 'smart city regionalism' square the circle? Urban Studies, Epub ahead of print DOI: 10.1177/0042098013478240.

Heurkens, E. \& Hobma, F. (2014) Private Sector-led Urban Development Projects: Comparative Insights from Planning Practices in the Netherlands and the UK, Planning Practice \& Research, 29:4, 350-369.

Hillier, J. (2000) Going round the back? Environment and Planning A, 32(1), pp. 33-54.

Hillier, J. (2003) Agonizing over consensus: why Habermasian ideals cannot be "real", Planning Theory, 2, pp. 37-55.

Hirst, P. (2000) Democracy and Governance In: Pierre, Jon (ed) Debating Governance: Authority, Steering and Democracy, pp. 13-25 (Oxford: Oxford University Press).

Häikiö, L. (2007) Expertise, representation and the common good: grounds for legitimacy in the urban governance network, Urban Studies, 44(11), pp. 2147-2162.

Häikiö, L. (2010) The Diversity of Citizenship and Democracy in Local Public Management Reform, Public Management Review, 12(3), pp. 363-384.

Inch, A. (2015) Ordinary citizens and the political cultures of planning: In search of the subject of a new democratic ethos, Planning Theory, 14(4), pp. 404-424.

Innes, J. \& Booher, D. (2010) Planning with complexity (New York: Routledge).

Kanninen, V. (2016). Yhdyskuntarakenteen ohjaaminen ja kaupunkiseutujen kehittäminen, in: S. Puustinen, R. Mäntysalo \& I. Karppi (Eds) Strateginen eheyttäminen kaupunkiseuduilla. 
Näkökulmia kestävän maankäytön ja julkisen talouden kysymyksiin, Valtioneuvoston selvitys- ja tutkimustoiminnan julkaisusarja 4/2016 (Helsinki: Prime Minister’s Office)

Kanninen, V., Bäcklund, P. \& Mäntysalo, R. (2013). Trading zone and the complexity of planning, in: A. Balducci, \& R. Mäntysalo (Eds) Urban Planning as a Trading Zone, pp. 159-177, Springer Urban and Landscape Perspectives 13 (Dordrecht: Springer)

Karppi, I., Henriksson, A., Andersson, S., Jordan, T. \& Niininen, T. (2008) Yhteistä visiota etsimässä. Kehittämiskohteena Lempäälän keskusta (Tampere: Tampere University Press).

Klijn, E-H. \& Koppenjan, J. (2012) Governance network theory: past, present and future. Policy \& Politics 40(4), pp. 587-606.

Laitio, M. \& Maijala, O. (2010) Alueidenkäytön strateginen ohjaaminen, Suomen ympäristö 28/2010 (Helsinki: Ympäristöministeriö).

Legacy, C., Curtis, C., \& Neuman, M. (2014) Adapting the deliberative democracy 'template' for planning practice, The Town Planning Review, 85(3), 319-340.

Leino, H. (2012) Boundary Interaction in Emerging Scenes: Two participatory Planning Cases from Finland, Planning Theory \& Practice, 13(3), pp. 383-396.

Leino, H. \& Laine, M. (2012) Do matters of concern matter? Bringing issues back to participation, Planning Theory, 11(1), pp. 89-103.

Lester, W. \& Reckhow, S. (2012) Network governance and regional equity: Shared agendas or problematic partners? Planning Theory, 12(2), pp. 115-138.

Luban, D. (1996) The Publicity Principle, in Goodin, R. (ed) The Theory of Institutional Design, pp. 154-198. Cambridge: Cambridge University Press.

McClymont, K. (2014) Stuck in the Process, Facilitating Nothing? Justice, Capabilities and Planning for Value-Led Outcomes, Planning Practice \& Research, 29(2), pp. 187-201.

MacLeod, G. (2011) Urban politics reconsidered: from growth machine to postdemocratic city? Urban Studies, 48(12), pp. 2629-2660.

MacLeod, G. \& Jones, M. (2011) Renewing urban politics, Urban Studies, 48(12), pp. 2443-2472.

MAL-verkosto (2010) Seudullisen MAL-toiminnan organisointi. Kooste MALkyselystä/osa B (Tampere: MAL-verkosto).

Metzger, J. (2011) Neither revolution, nor resignation: (re) democratizing contemporary planning praxis: A commentary on Allmendinger and Haughton's "Spatial planning, devolution, and new planning spaces", Environment and Planning C, Government and Policy, 29(2), pp. 191-196.

Miller, P. \& Rose, N. (2008) Governing the Present: Administering the Economic, Social and Personal Life (Cambridge: Polity Press).

Mouffe, C. (2000) The Democratic Paradox. London: Verso.

Mouffe, C. (2005) On the political. Abingdon: Routledge. 
Mäntysalo, R. \& Saglie, I-L. (2010) Private Influence Preceding Public Involvement: Strategies for Legitimizing Preliminary Partnership Arrangements in Urban Housing Planning in Norway and Finland, Planning Theory \& Practice, 11(3), pp. 317-338.

Mäntysalo, R., Jarenko, K., Nilsson, K-L. \& Saglie, I-L. (2014a) Legitimacy of informal strategic urban planning - observations from Finland, Sweden and Norway, European Planning Studies, 23(2), pp. 349-366.

Mäntysalo, R., Kangasoja, J.K. \& Kanninen, V. (2014b) Rakennemallit kaupunkiseutujen suunnittelussa - Strategisen maankäytön suunnittelun paradoksi. Ympäristöhallinnon raportteja 18/2014 (Helsinki: Ympäristöministeriö).

Mäntysalo, R., Kangasoja, J.K. \& Kanninen, V. (2015) The paradox of strategic planning: a theoretical outline with a view on Finland. Planning Theory \& Practice, 16(2), pp. 169-183.

Nurse, A. (2015) Bridging the Gap? The Role of Regional Governance in Delivering Effective Local Public Services: Evidence from England, Planning Practice \& Research, 30(1), pp. 69-82.

Olsson, J., \& Hysing, E. (2012). Theorizing Inside Activism: Understanding Policymaking and Policy Change from Below. Planning Theory \& Practice, 13(2), 257-273.

Ojaniemi, N. (2014) MAL(PE) - aiesopimusten sitoutumiseen vaikuttavat tekijät (Tampere: MALverkosto).

Purcell, J. (2013) The right to the city: the struggle for democracy in the urban public realm. Policy \& Politics, 43(3), pp. 311-327.

Ranciere, J (1995). On the shores of politics. London:Verso.

Rawls, J. (1971) A theory of Justice. Cambridge, MA: Harvard University Press.

Rawls, J. (1997) The Idea of Public Reason Revisited. The University of Chicago Law Review, 64(3), pp. 765-807.

Rosol, M. (2013) Vancouver's 'ecodensity' planning initiative: a struggle over hegemony?, Urban Studies, 50(11), pp. 2238-2255.

Sager, T. (2009) Planners' role: Torn between dialogical ideals and neo-liberal realities, European Planning Studies, 17(1), pp. 65-84.

Sam, M.P. \& Scherer, J. (2006) The steering group as policy advice instrument: A case of "consultocracy" in stadium subsidy deliberations, Policy Science, 39, pp. 169-181.

Sheppard, A., Burgess, S. \& Croft, N. (2015) Information is Power: Public Disclosure of Information in the Planning Decision-Making Process, Planning Practice \& Research, 30:4, 443456.

Skelcher, C., Klijn, E.H., Kübler, D., Sørensen, E. \& Sullivan, H. (2011) Explaining the Democratic Anchorage of Governance Networks. Evidence from Four European Countries, Administrative Theory \& Praxis, 33(1), pp. 7-38.

Stead, D. (2012) Best Practices and Policy Transfer in Spatial Planning, Planning Practice \& Research, 27(1), pp. 103-116. 
Stead, D. and Nadin, V. (2009) Planning cultures between models of society and planning systems, in: F. Othengraften \& J. Knieling (Eds) Planning Cultures in Europe: Diversity and Convergence, pp. 283-300 (Abington: Ashgate).

Sweeting, D. \& Copus, C. (2012) Whatever happened to local democracy? Policy \& Politics, 40(1), pp. 21-38.

$\mathrm{VN}=$ Valtioneuvosto (2009). Valtioneuvoston selonteko kunta- ja palvelurakenneuudistuksesta. VNS 9/2009.

Wagenaar, H. (2011) Meaning in Action: Interpretation and Dialogue in Policy Analysis (M.E. Sharpe: New York, London).

Waterhout, B., Othengrafen, F. \& Sykes, O. (2013) Neo-liberalization processes and spatial planning in France, Germany, and the Netherlands: An exploration, Planning Practice \& Research, 28(1), pp. 141-159.

Wilkinson, C. (2011) Strategic navigation: in search of an adaptable mode of strategic spatial planning practice, Town Planning Review, 82(5), pp. 595-613.

Yanow, D \& Schwartz-Shea, P. (Eds) (2006) Interpretation and Method. Empirical Research Methods and the Interpretive Turn (M.E. Sharpe: New York, London).

Zizek, S (2000) Holding the place, in: Butler, J., Laclau, E. and Zizek, S. (eds) Contingency, hegemony, universality: contemporary dialogues on the Left, 308-29. London:Verso. 